\title{
Bruxism, stress and anxiety in young people
}

\author{
Bruxismo, estrés y ansiedad en jóvenes
}

CAPETILLO-HERNÁNDEZ, Guadalupe Rosalía†*, TORRES-CAPETILLO, Evelyn Guadalupe, OCHOA-MARTINEZ, Rosa Elena and FLORES-AGUILAR, Silvia Georgina

Universidad Veracruzana, Facultad de Odontología, Región Veracruz

ID $1^{\text {st }}$ Author: Guadalupe Rosalía, Capetillo-Hernandez / ORC ID: 0000-0002-2033-4660, Researcher ID Thomson: S7875-2018, CVU CONACYT ID: 386320

ID $1^{\text {st }}$ Coauthor: Evelyn Guadalupe, Torres-Capetillo / ORC ID: 0000-0003-0576-0327, Researcher ID Thomson: T-16802018, CVU CONACYT ID: 308188

ID $2^{\text {nd }}$ Coauthor: Rosa Elena, Ochoa-Martínez / ORC ID: 0000-0002-0676-6387

ID $3^{\text {rd }}$ Coauthor: Silvia Georgina, Flores-Aguilar / ORC ID: 0000-0002-5857-4969

DOI: $10.35429 /$ EJS.2019.11.6.16.19

Received September 10, 2019; Accepted December 15, 2019

\begin{abstract}
Introduction. The bruxism is the act of clenching and/or grinding the teeth, a habit that compromises the orofacial region. It is often associated with emotional aspects, such as anxiety and stress, and can lead to alterations in orofacial structures, functional modifications and social repercussions. (1). The etiology of bruxism is unclear, but the condition has been associated with stress, occlusal disorders, allergies and sleep positioning. (2). Objective. To determine the relationship between bruxism, stress and anxiety in university students of the Universidad Veracruzana. Methodology. We conducted a descriptive, observational, cross-sectional study in students of the Faculty of Engineering. Evaluation instruments were applied to measure anxiety, stress and the presence of bruxism, as well as the clinical examination that allowed to diagnose the presence of manifestations of bruxism. Contribution. Comparing the level of stress and anxiety of the individuals who presented dental damage and those who did not present it, no significant differences were found between the two groups, which confirms the uncertain etiology of this pathology. However, it is essential to note that the study was carried out in university students and that at an early age, they present important manifestations of bruxism.
\end{abstract}

Bruxism, Stress, Anxiety

\section{Resumen}

Introducción. El bruxismo que es el acto de apretar y/o rechinar los dientes, un hábito que compromete la región orofacial. A menudo se asocia con aspectos emocionales, como la ansiedad y el estrés, y puede dar lugar a alteraciones en las estructuras orofaciales, modificaciones funcionales y repercusión social. (1) La etiología del bruxismo no está claro, pero la condición se ha asociado con el estrés, trastornos oclusales, las alergias y el posicionamiento del sueño.(2). Objetivo. Determinar la relación entre bruxismo, estrés y ansiedad en los estudiantes universitarios de la Universidad Veracruzana. Metodología. Se realizó un estudio descriptivo, observacional, transversal. En estudiantes de la Facultad de Ingeniería. Se aplicaron instrumentos de evaluación para medir ansiedad, estrés y la presencia de bruxismo, así como la exploración clínica que permitiera diagnosticar la presencia de manifestaciones de bruxismo. Contribución Comparando el nivel de estrés y ansiedad de los individuos que presentaron daño dental y los que no lo presentaron, no se encontraron diferencias significativas entre los dos grupos, lo cual confirma la etiología indefinida de esta patología. Sin embargo es importante señalar que el estudio se realizó en jóvenes universitarios y que a temprana edad presentan manifestaciones importantes de bruxismo.

Bruxismo, Estrés, Ansiedad

Citation: CAPETILLO-HERNÁNDEZ, Guadalupe Rosalía, TORRES-CAPETILLO, Evelyn Guadalupe, OCHOAMARTINEZ, Rosa Elena and FLORES-AGUILAR, Silvia Georgina. Bruxism, stress and anxiety in young people. JournalSpain. 2019. 6-11: 16-19

*Correspondence to Author (gcapetillo@uv.mx)

$\uparrow$ Researcher contributing as first author. 


\section{Introduction}

A habit can be defined as practicing the same act unconsciously with variation in intensity and frequency. When a habit is present, a behavior pattern can be established, which is fixed by repetition and continuity, with an attitude that lacks control of consciousness itself. Many young students, unable to calm or control their anxiety, do not know how to resist their distress and generate repetitive habits or behaviors to release tension.

Some authors refer that parafunctional oral habits are repetitive functions of the masticatory system, often subconscious, different qualitatively and quantitatively from their physiological function. Bruxism or tooth grinding constitutes a harmful parafunction for the masticatory system. If we consider the great forces that can be exerted on the teeth and joints during their parafunctional activity, permanent damage to the associated oral structures is evident. Some young people who present bruxism may present symptoms of painful temporomandibular joint dysfunction, while others may present deterioration of the periodontal structures or excessive wear of the teeth.

There is no doubt that bruxism is directly related to psychic tension and frustration. (Martinez, 2002).

There is evidence that bruxism is aggravated when muscular hyperactivity is increased. That is why it is considered unreasonable that an adjustment of the occlusion would cure the habit when the dominant factor is stress. Patients with bruxism exert tremendous occlusal force and spend most of their time with their teeth clenched, which increases an overload on any restoration.

Sleep bruxism and waking bruxism are common conditions among adolescents, with prevalence rates of subjective perception being slightly higher than those derived from most large-scale studies on adults. (Van Selms MK, 2013)

\section{Bruxism and its relationship to stress and anxiety}

Bruxism, also known as "occlusal neurosis," shows how dentists have begun to link neurosis with the appearance of bodily disorders over the past decades.

There are different ways of reacting, some more fragile and more sensitive organs in front of the consequences of an emotional state, there could be many examples, but in all cases, there is a unique psychosomatic matrix.

People with oral habits like bruxism are trying to eliminate the tension produced by the stress and anxiety caused by the pressures of everyday life.

A person can unconsciously use a defense mechanism that makes life more tolerable. Basic needs such as shelter and food may be instinctive but, since they are now partially met by society, secondary or social motives and desires become dominant, such as recognition, superiority, love and ego gratification.

If the individual does not achieve the desired success concerning these desires, he feels frustrated, and this frustration leads to the formation of tension. Many situations in modern society promote feelings of maladjustment.

Because of these social restrictions, an individual may not be able to discharge prolonged or intense emotional stress through physical or verbal activity. Anxiety, anger, or fear suppressed by the individual, which cannot be expressed openly, are the most common causes of stress. Psychological stress must be released, or it will become intolerable, leading to pathological states of anxiety, and the individual will become mentally ill. One method used to dissipate stress and anxiety is bruxism.

\section{Symptoms of Bruxism}

Bruxism may have one or more of the following clinical signs and symptoms:

- $\quad$ Facets of damage on the teeth (dimples on the occlusal surfaces of the back teeth).

Excessive and uneven occlusal and/or incisal damage. 
- $\quad$ Increased muscle tone and resistance to jaw manipulation.

Hypertrophy of the masticatory muscles, especially the masticatory and temporal muscles.

- $\quad$ Increased mobility of the pieces, without apparent parodontopathy.

Tooth migration.

- $\quad$ Dull percussion sound.

- Feeling of tiredness in the chewing muscles, when waking up in the morning.

- $\quad$ Locking of the jaw, tendency to bite the lips, cheeks or tongue.

Chewing muscles sore on palpation.

Pain or discomfort in the temporomandibular joints (spontaneous or caused by palpation)

Chewing and/or swallowing with toothache.

Pulp sensitivity to cold, sweet or sour.

Audible sounds of bruxism (these do not always occur and are usually referred to by family members or people close to them).

\section{Methodology to be developed}

This is an applied, observational, transversal and prospective study carried out at the Faculty of Engineering of the Universidad Veracruzana, Veracruz region, in the period between February and August 2018, with a sample of 250 students between 18 and 25 years old, belonging to different socio-economic strata. We implemented a probabilistic sampling.

\section{General Objective}

To determine the relationship between bruxism, stress and anxiety in university students of the Universidad Veracruzana.

\section{Instruments used}

\section{Clinical history}

The dental clinical history is a medical-legal instrument, of great utility for the personnel of the area of the health in the study of the patients. Test of Attitudes that Cause Stress (Batista, 2007). The test is aimed at reflecting on the degree to which each person is a stressprovoking agent in themselves. It was elaborated by Dr. Jorge Grau A. It consists of a series of reagents that the subject must evaluate with the frequency that occurs to them.
The result of the questionnaire allows the classification of the subjects in the following groups: a) high stress (88-116 points), b) moderate stress (59- 87 points), c) soft stress (3058 points) and d) low stress (29 points or less).

Experiential self-report (Batista, 2007) consists of presenting the subject with a list of terms that express emotional states that can be experienced at any time, one of them being Anxiety. The subject must evaluate each of the terms according to the degree or level of depth or intensity with which he or she experiences them, such as little, moderate or intense anxiety.

\section{Results}

Comparing the level of stress of individuals who had dental damage and those who did not, no significant differences were found between the two groups. As shown in table 8, in both groups, the trend was towards "moderate stress," followed by "mild stress." Among the patients who did not present dental damage, only one subject was observed in the extreme levels of stress, i.e. "high" and "low."

About the level of stress manifested by the students, we found that $62.8 \%$ of the subjects who presented dental damage were among those who manifested "moderate stress" and 37.2\% in "mild stress." It is important to point out that $46.9 \%$ of the total population that manifested "moderate" stress has dental damage, as well as $52.3 \%$ of those who present "soft" stress.

Subjects with dental damage presented a mean of $56.16 \pm 9.96(\mathrm{SD})$ on the anxiety test. This mean was not statistically different from the one found in the subjects without bruxism: $56.25(\mathrm{t}=$ -.073, $\mathrm{gl}=248, \mathrm{p}=.942$ n.s.)

Occlusal wear, stress and anxiety

When comparing the level of stress between the subjects who presented occlusal damage and those who did not, no significant differences were found between the two groups. As shown in table 9 , in both groups, the mode was at the level of "mild stress," followed by "moderate stress." Among the patients who did not present occlusal damage, only one subject was observed in the extreme levels of stress, i.e. "high" and "low." 
It is important to point out that the students who presented bruxism independently of their gender, $44.8 \%(\mathrm{n}=112)$ presented bruxism, and $55.2 \%(\mathrm{n}=138)$ did not present bruxism. These results are shown in Table 2, as well as the percentage of students who presented dental grinding and clenching. It is important to note that $88.8 \%(\mathrm{n}=222)$ in the case of grinding and $75.2 \%(\mathrm{n}=188)$ in the case of clenching, do not know if they present it.

Subjects with occlusal damage had a mean of $56.48 \pm 9.71$ (SD) on the anxiety test. This mean was not statistically different from that found in subjects without occlusal damage: $56.09(\mathrm{t}=.279, \mathrm{gl}=248, \mathrm{p}=.781 \mathrm{n} . \mathrm{s}$.

\section{Conclusions}

Bruxism is identified as a pathology of undefined etiology, but it is closely related to the emotional state, stress management and stressors among young people. We consider in this study that it is related to the state of mental health of students. Moreover, it is necessary to promote at university level real programs of prevention and attention for the needs of Mental Health of our students.

Consequently, it can be concluded that:

- A significant part of the population studied was diagnosed as bruxers, who are very young, and this constitutes a fundamental data for the health of the economically active population of the country in some years, which was also presented independently of gender.

- The presence of stress and anxiety in bruxist and non-bruxist patients did not represent a statistically significant data. This leads us to the theory of multifactorial etiology, which is not very specific to this pathology.

\section{References}

Alves, AC; Alchieri, JC; Barbosa, G.A. 2013. El Bruxismo, implicaciones de la masticación y la ansiedad. Acta Odontológica Latinoamericana. 26 (1): $15-22$
Batista, M; García, O; Pérez, G. (2007). "Repercusión estomatognática del bruxismo como somatización del estrés". Revista electrónica de portales médicos.com. September 2007.

Capetillo-Hernandez, G.R, Torres-Capetillo, E. G, Tiburcio-Morteo, L., \& Flores-Aguilar, S. (2018). Mejoramiento de la salud integral de los estudiantes universitarios a partir de la educación y atención de la salud oral. Revista de Técnicas de, 6.

Martinez R.E. (2002). Rehabilitación y Reconstrucción Oclusal. Mexico DF. Ediciones Cuellar

Murali, RV; Rangarajan, P; Mounissamy, A. (2014). El bruxismo: discusión conceptual y revisión. Journal of Pharmacy \& BioAllied SciencesApril; 7 (Suppl 1); S265-S270

Van Selms MK, Visscher CM, Naeije M, Lobbezoo F El bruxismo y factores asociados en adolescentes holandeses. 2013 Comunidad Dent Oral Epidemiol 2013 Aug; 41 (4): 353-63. doi: 10.1111 / cdoe.12017. Epub 2012 Nov 3. 